\title{
SMALl MAMMAL DiSTRIBUTIONS IN RIPARIAN AND ADJACENT HABITATS OF GraNd TETON NATIONAL PARK, WYOMING
}

\author{
C. BRIAN VILLALOBOS $\bullet$ BARRY L. KELLER \\ DEPARTMENT OF BIOLOGICAL SCIENCES \\ IDAHO STATE UNIVERSITY • POCATELLO
}

\section{- INTRODUCTION}

Riparian ecosystems are among the most productive biological systems providing food, water, shade, and cover for wildlife (Thomas et al. 1979a). Furthermore, they may display a greater diversity of plant and animal species and vegetative structure than adjacent ecosystems (USDI 1986). Thomas et al. (1979a) provide a descriptive definition which characterizes riparian ecosystems by the presence of trees, shrubs, or herbaceous vegetation that require free or unbound water, or conditions that are more moist than those of the surrounding areas. They suggest that more wildlife species depend entirely on or spend disproportionally more time in riparian habitat than any other.

Although the importance of riparian vegetation to wildlife has been apparent since the 1970's, its overall importance to vertebrate species has not been widely studied, especially in the western United States (Patton 1977). Elsewhere, there is a paucity of information on the ecological role of small mammals in riparian areas. Because small vertebrate species may serve as an especially important link in the food chain of threatened, endangered, or reintroduced species, and because small mammal species seem to be compacted in environmentally diverse areas, analysis of riparian vertebrate communities should provide important insights in mechanisms of habitat subdivision and utilization. Clearly, riparian areas contain a greater variety of species than adjoining forest or upslope habitats (Cross 1985).
The effect of patch shape on the number of species occupying riparian habitats also has received limited attention (Patton 1975). Because riparian habitat consists of a narrow patch, the elongated shape of riparian areas produces a low interior-tohigh-edge ratio which may facilitate or enhance ecological processes, especially the production and dispersal of small mammals. Unfortunately, no documentation exists about patterns of mammalian movement along stream corridors (Forman and Godron 1986). Thus, the importance of the relative use of the edge, riparian, and upland areas by small mammals needs to be investigated, especially in forested mountain land, where riparian areas tend to have smaller areal extent and economic value than upslope vegetation (Swanson et al. 1982).

The principle objective of our study was to determine if consistent environmental and landscape features could be found in western riparian, edge, and upland communities, and if these features affected residency of small mammals in Grand Teton National Park. Three independent study sites were studied from June, 1991 through October, 1991 in preparation for a proposed long-term analysis of the role of riparian areas in production of small mammals.

\section{- STUdY AREA}

Grand Teton National Park, Wyoming, established in 1926, encompasses approximately 
125,759 ha in northwestern Wyoming. The average temperature is $1.3 \mathrm{C}$. The mean annual precipitation is approximately $8.5 \mathrm{~cm}$ which includes an average snowfall of $53.9 \mathrm{~cm}$. All study sites are located in the southern section of the Park. Each site was selected for study based upon accessibility and previous research that suggested small mammals were abundant (Villalobos and Keller 1991). Our site location on Beaver Creek, a second-order stream segment, is $2048 \mathrm{~m}$ in elevation. The site at Cottonwood Creek, a fourth-order stream segment, is $2060 \mathrm{~m}$ in elevation. The site at Glacier Gulch, a first-order stream, is $2103 \mathrm{~m}$ in elevation. Each site has a variety of different soil types and vegetation and small mammal species. Reed (1952) and Shaw (1958) have described the general vegetation of Grand Teton National Park, Wyoming, and the geology of the Teton landscape has been described by Love and Reed (1971). For detailed vegetation, soils, and methodology see Villalobos and Keller (1992).

\section{RESULTS AND DISCUSSION}

\section{SMALL MAMMALS}

During 3,207 live-trap nights undertaken at the three independent sites, 455 individuals were captured during the 1991 field season. Eight species of rodents and one species of shrew were captured. For example the results of a third tier of captures obtained in these areas are presented in Table 1. A significant difference in species diversity of the rodent species is apparent among areas, being highest at the Glacier Gulch site. On the basis of these data, riparian areas in Grand Teton National Park appear to contain more microtine rodents and shrews than other areas. Riparian areas have highest species diversity. When data are pooled, Pielou's J' = $0.712,0.498$, and 0.397 at the riparian, edge, and upland habitats, respectively. The edge and upland usually contain the greatest abundance of small mammals.

Species composition and the relative density were not seasonally consistent as the trapping season progressed. At Beaver Creek, it decreased (Table 2). At Cottonwood Creek, species composition increased through the season while relative density peaked during mid-season. Species composition increased through the season at Glacier Gulch and relative density peaked during mid-season. Two species of small mammal account for these seasonal changes in species composition and relative density: the deer mouse (Peromyscus maniculatus), and the southern red-backed vole (Clethrionomys gapperi). These two species may be more numerous in some areas, and their reproductive patterns may account for these seasonal fluctuations in such areas.

In riparian habitat, the deer mouse dominates at Beaver and Cottonwood Creeks, whereas, the southern red-backed vole has the highest percentage of capture at Glacier Gulch. The masked shrew (Sorex cinereus) has the second highest capture percentage at Beaver and Cottonwood Creeks while the deer mouse is second highest at Glacier Gulch. Along with the shrew, microtine rodents such as the water vole (Microtus richardsoni), meadow vole (Microtus pennsylvanicus), montane vole (Microtus montanus), and the long-tailed vole (Microtus longicaudus) are rare species found almost exclusively in riparian habitats. For these species, riparian habitats appear to contain optimal foraging and reproductive sites as well as more extensive cover and water when compared to upland sites. In edge habitat, the deer mouse dominates all three areas. At all three areas, the yellow-pine chipmunk (Tamias amoenus) is found in greatest abundance at the edge. It is assumed that individual microtines and shrews move from the interior of the riparian habitat to the "edge" while exploring or searching for food. The riparian corridor, which may include the inhetent edge, would most likely be their primary area of movement. In upland habitat, species diversity is lowest with the southern red-backed vole at Beaver Creek and the deer mouse at Cottonwood Creek and Glacier Gulch dominating all three areas. The yellow-pine chipmunk is abundant in the upland forests of Beaver Creek and Glacier Gulch. However, the masked shrew and the montane vole are rare species in these habitats, and those caught could be dispersing individuals.

Anthony et al. (1987), Clark (1975), Cross (1985), Doyle $(1986,1990)$, and MacCraken et al. (1985) also reported the deer mouse as the most abundant rodent in their respective studies. Their study areas were partitioned into different habitats which included a riparian habitat-type and variable nonriparian habitats. The deer mouse is likely the most ubiquitous small mammal in the Park. Doyle (1986), whose study was conducted on the west slope 
Table 1. Total captures and kinds of small mammals live trapped during the third sampling undertaken in riparian (R), edge (E), and upland $(\mathrm{U})$ habitats at Beaver Creek, Cottonwood Creek, and Glacier Gulch during September and October, 1991.

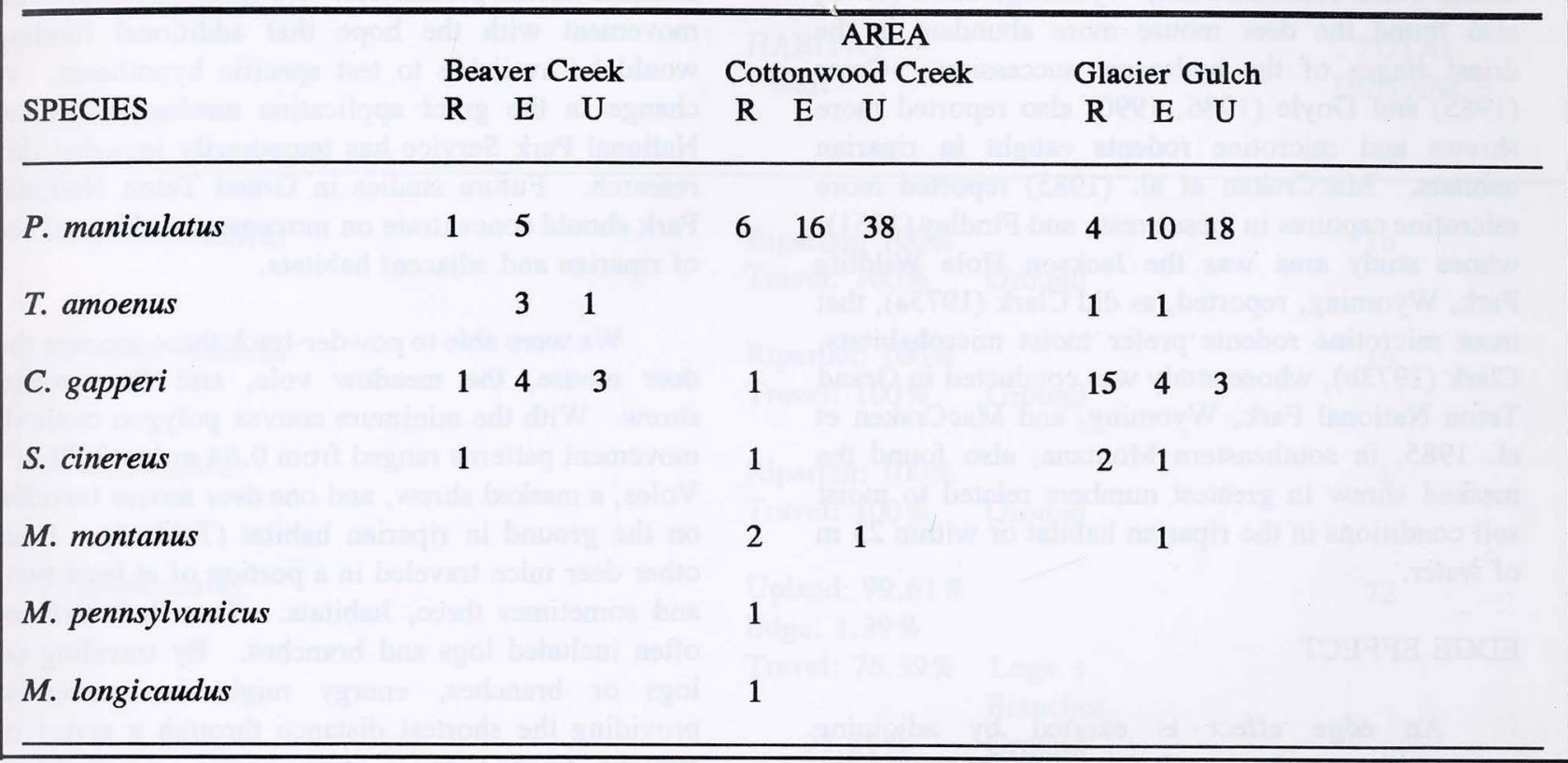

Table 2. Total species captured, number of live-trap nights, and relative density per 500 trap nights during trapping intervals at Beaver Creek, Cottonwood Creek, and Glacier Gulch, 1991.

\begin{tabular}{llll}
\hline Area and Season & Total catch & Trap nights & Relative density
\end{tabular}

\begin{tabular}{lccc}
$\begin{array}{l}\text { Beaver Creek } \\
\text { mid June } \\
\text { mid July }\end{array}$ & 32 & 360 & 44.4 \\
late September & 25 & 360 & 34.7 \\
$\begin{array}{l}\text { Cottonwood Creek } \\
\text { late June }\end{array}$ & 19 & 357 & 26.6 \\
early August & & & \\
mid October & 38 & 339 & 56.0 \\
Glacier Gulch & 113 & 360 & 156.9 \\
early July & 67 & 354 & 94.6 \\
mid August & & & \\
mid September & 32 & 360 & 44.4 \\
& 69 & 360 & 95.8 \\
\hline
\end{tabular}


of the Cascade Range in Oregon, found the deer mouse more numerous in riparian habitats, whereas, our study indicates that this species is more numerous in the edge and upland habitats. In his studies in Grand Teton National Park, Wyoming, Clark (1975) also found the deer mouse more abundant in the driest stages of the hydrosere succession. Cross (1985) and Doyle $(1986,1990)$ also reported more shrews and microtine rodents caught in riparian habitats. MacCraken et al. (1985) reported more microtine captures in these areas, and Findley (1951), whose study area was the Jackson Hole Wildlife Park, Wyoming, reported, as did Clark (1973a), that most microtine rodents prefer moist microhabitats. Clark (1973b), whose study was conducted in Grand Teton National Park, Wyoming, and MacCraken et al. 1985, in southeastern Montana, also found the masked shrew in greatest numbers related to moist soil conditions in the riparian habitat or within $25 \mathrm{~m}$ of water.

\section{EDGE EFFECT}

An edge effect is exerted by adjoining communities on the population structure within the ecotone which often contains greater numbers of species and higher densities of some species than either adjoining communities. An edge effect for small mammal captures was found in every area at the edge but at different sampling periods. In the first sampling of the edge at Beaver Creek, the deer mouse, southern red-backed vole, and yellow-pine chipmunk combine for a total capture of 16 . In the second sampling of the edge at Cottonwood Creek, the deer mouse alone accounts for a total capture of 43, and at the edge in Glacier Gulch, the deer mouse, masked shrew, yellow-pine chipmunk, montane vole, and southern red-backed vole account for a total capture of 28. In the third sampling at Beaver Creek, the deer mouse, yellow-pine chipmunk, and southern red-backed vole account for a total capture of 12. At the edge, it is apparent that animals have access to both riparian and upland areas and may utilize benefits available in both habitats with less energy expenditure.

\section{MOVEMENT PATTERNS \& HABITAT USE}

During 1991, we began describing movement patterns with powder-tracking, because we believed that movement patterns may provide important insights needed to develop management strategies for riparian and adjacent habitats. However, our movement studies were limited because of time constraints associated with the short trapping season, our multiple site trapping design, and the need to estimate habitat parameters. We initiated research on movement with the hope that additional funding would be available to test specific hypotheses. A change in the grant application mechanism to the National Park Service has temporarily impeded this research. Future studies in Grand Teton National Park should concentrate on movement within and out of riparian and adjacent habitats.

We were able to powder-track three species: the deer mouse, the meadow vole, and the masked shrew. With the minimum convex polygon method, movement patterns ranged from $0.64 \mathrm{~m}^{2}$ to $2.22 \mathrm{~m}^{2}$. Voles, a masked shrew, and one deer mouse traveled on the ground in riparian habitat (Table 3). Four other deer mice traveled in a portion of at least two, and sometimes three, habitats. Travelled surfaces often included logs and branches. By traveling on logs or branches, energy might be conserved providing the shortest distance through a series of straight lines between two points, a condition affecting the surface used in areas containing debris. Our initial data suggest that downfall may be an important factor in movement outside of riparian areas, but that most of the micro-surface used in riparian areas includes bare ground. The importance of this area should be studied extensively. The data also suggest that, depending on the habitat under study, specific sites used by small mammals should be assessed when determining trap locations.

\section{CLUSTER ANALYSIS}

Often, the small-mammal ecologist describes patterns of distributions in terms of abiotic and biotic associations recognized a priori. This analysis, which allows small-mammal fauna to define environmental characteristics, was designed to answer: 1) How are riparian habitats uniquely different than adjacent edge and upland habitats with respect to small mammals? The study of microhabitat of nine small-mammal species suggests that small mammals in the riparian habitat and their abiotic and biotic descriptors are more closely related than those of the edge and upland habitats. Furthermore, cluster distances suggest that riparian habitats are distinct when compared with edge 
Table 3. Small-mammal species, habitat use, and total distance (m) traversed as a result of powder-tracking analysis in Grand Teton National Park, Wyoming.

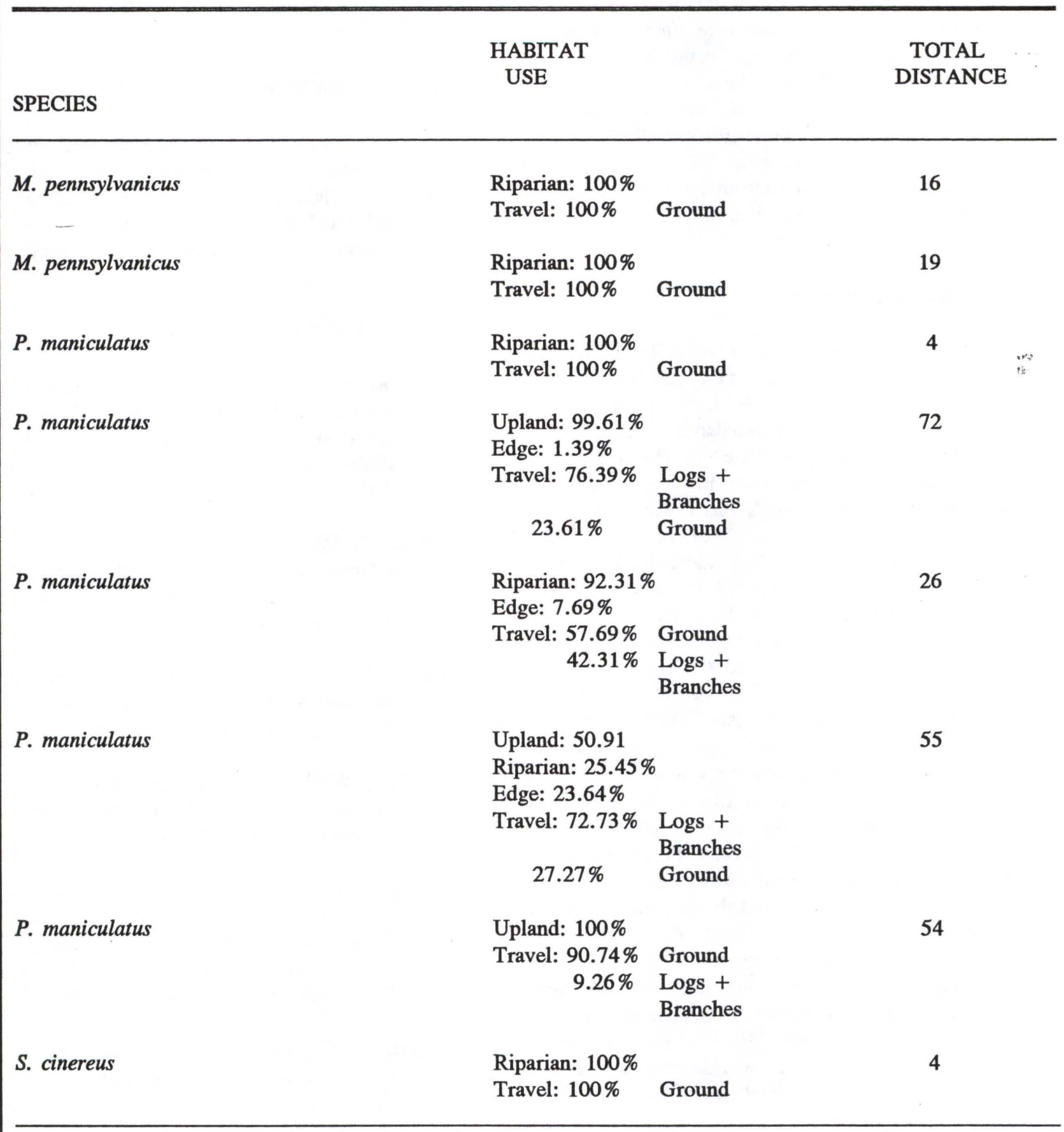

and upland habitats. In general, riparian ecosystems offer unique and diverse small-mammal habitats by providing food, water, cover, and variable microclimates. Our study demonstrates that there is a greater availability of soil moisture to plants in the riparian habitats, and in combination with deeper litter layers, produces greater vertical vegetative diversity and density of plants which provide cover 
and food. This results in a greater diversity of small mammals. Most importantly, microtines and shrews may be provided with critical resources found only within the stream corridor. The stream corridor and the inherent edge may function as source habitats that are responsible for the majority of juvenile production of both microtines and shrews, and Peromyscus, respectively. The upland habitats may serve as "dispersal sinks" (Lidicker 1975). These areas likely provide marginal habitats where some small-mammal individuals from the riparian and edge areas take refuge and survive.

\section{- CONCLUSIONS}

From our study areas in Grand Teton National Park, Wyoming, it is evident that species diversity is greatest in the riparian habitats or the stream corridor, and the greatest abundance of individuals is usually found at the inherent edge. We believe that microhabitats in riparian areas provide some smallmammal species with conditions that are conducive for successful reproduction. These productive areas serve as "nurseries" - a place where small-mammal young are essentially prepared for colonization of vacant habitats. Some individuals may remain throughout their life cycle in the stream corridor while others may not. And the stream corridor obviously retains the breeding core of some species unable to colonize other habitats. The inherent edge thus functions as an "open gate" which allows dispersers access both into and out of areas where reproductive success is more likely. A few species that live on or near the inherent edge may be reproductively successful, because they have access to both riparian and upland areas. They may utilize the benefits available to both habitats with less energy expenditure. Yahner (1988) emphasizes that additional data are needed to better understand community changes along edges and to manage edges for the benefit of wildlife in various landscapes. The upland areas may serve as "dispersal sinks" (Lidicker 1975). These areas likely provide marginal habitats where some small-mammal individuals from the riparian and edge areas take refuge and survive while waiting for optimal reproductive sites. Therefore, we emphasize and recommend that successful management plans must consider and adopt a stream ecosystem concept which provides management for an entire stream drainage basin. This concept must include the biotic and abiotic components of the stream and the riparian, inherent edges, and a considerable portion of the upland areas because each has a major impact on the other.

\section{$\checkmark \quad$ ACKNOWLEDGEMENTS}

We are grateful to and especially thankful for field assistance from Marlys, Joshua, Kelly, and Jennifer Villalobos. We also thank Idaho State University and the Steering Committee of the UWNPS Research Center for their financial support.

\section{- Literature Cited}

Anthony, R. G., E. D. Forsman, G. A. Greèen, G. Witmer, and S. K. Nelson. 1987. Small mammal populations in riparian zones of different-aged conifer forests. Murrelet 68:94102.

Clark, T. W. 1973a. Local distributions and interspecies interactions in Microtines, Grand Teton National Park, Wyoming. Great Basin Naturalist 33:205-217.

Clark, T. W. 1973b. Distribution and reproduction of shrews in Grand Teton National Park, Wyoming. Northwest Science 47:128-131.

Clark, T. W. 1975. Ecological notes on deer mice in Grand Teton National Park, Wyoming. Northwest Science 49:14-16.

Cross, S. P. 1985. Responses of small mammals to forest riparian perturbations. In: Riparian Ecosystems and Their Management: Reconciling Conflicting Uses. U.S. For. Ser. Gen. Tech Rep. Rm. No. 120. 269-275.

Doyle, A. T. 1986. Small mammal micro- and macrohabitat selection in streamside ecosystems. Dissertation Abstract Int., (B) 46 (8). 2590.

1990. Use of riparian and upland habitats by small mammals. J. of Mammal. 71:14-23. 
Findley, J. S. 1951. Habitat preference of four species of Microtus in Jackson Hole, Wyoming. J. of Mammal. 32:118-120.

Forman, R. T. T. and M. Godron. 1986. Landscape Ecology. John Wiley \& Sons, Inc. $619 \mathrm{pp}$.

Lidicker, W. Z. Jr. 1975. The role of dispersal in the demography of small mammal populations. In: Small Mammals: Their Productivity and Population Dynamics, ed. K. Petruscwicz, F. B. Golley, L. Ryszkowski, pp. 103-128. New York-London: Cambridge University Press. $451 \mathrm{pp}$.

Love, J. D., and J. C. Reed, Jr. 1971. Creation of the Teton landscape. Moose, Wyoming: Grand Teton Natural History Association.

MacCraken, J. G., D. W. Uresk, and R. M. Hansen. 1985. Rodent vegetation relationships in southeastern Montana, USA. Northwest Sci. 59:272-278.

Patton, D. R. 1975. A diversity index for quantifying habitat "edge". Wildlife Society Bulletin, 3:171-173.

Patton, D. R. 1977. Riparian research needs. In: Johnson, R. R. and D. A. Jones, tech. coords., Importance, Preservation, and Management of Riparian Habitat: A Symposium. USDA - For. Ser. Gen. Tech. Rep. R. No. 43. 80-82.

Reed, J. F. 1952. The vegetation of Jackson Hole Wildlife Park, Wyoming. American Midland Naturalist, 48:700-729.

Shaw, R. J. 1958. Vascular plants of Grand Teton National Park, Wyoming. American Midland Naturalist, 59:146-166.
Swanson, F. J., S. V. Gregory, J. R. Sedell, and A. G. Campbell. 1982. Land-water interactions: the riparian zone, pp. 267-291. In: R. L. Edmonds (ed.), Analysis of Coniferous Forest Ecosystems in the Western United States. US/IBP Synthesis Series 14. Hutchinson Ross Publ. Co., Stroudsberg, PA.

Thomas, J. W., C. Maser, and J. E. Rodiek. 1979a. Riparian Zones, In: Wildlife Habitats in Managed Rangelands - the Great Basin of Southeastern Oregon, eds. J.W. Thomas and C. Maser. USDA-For. Ser. Gen. Tech. Rep. PNW-80, pp. 21-31.

USDI. 1986. Riparian area management. Bureau of Land Management, Washington, D. C., 4 pp.

Villalobos, C. B., and B. L. Keller. 1991. The influence of riparian and adjacent habitats on small mammal distributions in Grand Teton National Park, Wyoming. Semiannual Report, University of Wyoming-National Park Service Research Center, 8 pp.

Villalobos, C. B., and B. L. Keller. 1992. The influence of riparian and adjacent habitats on small mammal distributions in Grand Teton National Park, Wyoming. Final Report, UWNPS Research Center. 58 pp.

Yahner, R. H. 1988. Changes in Wildlife communities near edges. Conserv. Biol. 2:333339. 